\title{
Acetylation Phenotype in Abstinent Alcoholics
}

\author{
Sally K. Guthrie, PharmD, Elizabeth A. Lane, PhD, Markku Linnoila, MD, PhD
}

\begin{abstract}
No association between acetylation phenotype and alcoholism was discovered. Fifty-four percent of both the alcoholic patients and healthy volunteers were rapid acetylators. Acetylation phenotyping is not helpful to the investigation of the genetics of alcoholism.
\end{abstract}

$\mathbf{T}$ HERE HAS BEEN an accumulation of data suggesting that vulnerability to alcoholism is markedly influenced by genetic factors. Strongest evidence for this has come from studies in which a higher level of concordance for alcoholism was found among identical than fraternal twins, ${ }^{1.2}$ and studies of adopted offspring of alcoholics. ${ }^{3-6}$ The identification of a genetic marker for alcoholism would narrow the search for a "vulnerability gene." Several blood proteins have been reported to differ in alcoholics when compared to controls, ${ }^{7}$ and platelet MAO and adenylate cyclase activity have been noted to be low in alcoholics. ${ }^{8-10}$ However, it is unclear whether or not these apparent changes predate the development of alcoholism. A biological marker that correlates with a genetic vulnerability towards alcoholism has not been identified. One approach is to compare the occurrence of alcoholism to the expression of a readily identifiable phenotype that is known to be the result of two alleles at a autosomal gene locus, as is the acetylation phenotype. ${ }^{11,12}$

Other reasons for determination of any cosegregation of alcoholism with the rapid or slow acetylation phenotype have to do with a reported increase in acetylation clearance of drugs when administered with alcohol ${ }^{11.13}$ and the metabolism of serotonin by $\mathrm{N}$-acetyltransferase. Serotonin has been hypothesised to exhibit abnormal metabolism in patients with alcoholism. ${ }^{14}$ It has been reported that the cerebrospinal fluid concentrations of the serotonin metabolite, 5-hydroxyindole acetic acid, are low in subjects who display pathological impulsive behavior. ${ }^{15-18}$ Also, personality traits associated with impulsive behavior have been ascribed to Type 2 alcoholics, who exhibit a strong family history of paternal alcoholism. ${ }^{14}$

\section{METHODS}

Acetylation phenotype was established in 63 subjects: 37 abstinent alcoholics and 26 control subjects. All subjects were Caucasian, 18 years

From the College of Pharmacy, University of Michigan, Ann Arbor, Michigan; and the Laboratory of Clinical Studies, Division of Intramural Clinical and Biological Research. National Institute on Alcohol Abuse and Alcoholism, Bethesda, Maryland.

Received for publication March 10, 1988; revised manuscript received July 29, 1988; accepted August l. 1988.

Reprint requests: Sally K. Guthrie, PharmD, College of Pharmacy,

University of Michigan, Ann Arbor. MI 48109-1065.

Copyright $@ 1989$ by The Research Society on Alcoholism. of age or older and unrelated to any other volunteer. None exhibited any abnormalities on physical screening, which included a history and physical examination, complete blood count with differential, platelet count, liver enzymes, albumin, BUN, creatinine, and urinalysis. Although liver bjopsy was not performed, any alcoholic subject with abnormal liver enzyme values was excluded. Volunteers and alcoholic subjects were drug-free, with the exception of two controls; one taking conjugated estrogens and the other atenolol. All subjects with a history of allergy to sulfa drugs or glucose-6-phosphate dehydrogenase deficiency were excluded. Acoholic patients were diagnosed as alcohol dependent according to DSM-III' ${ }^{19}$ criteria based on a structured interview using the Schedule for Affective Disorders and Schizophrenia-Lifetime Version. ${ }^{20}$ Control subjects were screened with these same instruments and were admitted into the study only if they were free of any drinking problems and had no alcoholic first degree relative. All abstinent alcoholics and some controls stayed on an inpatient ward located at the National Institute of Health Clinical Center in Bethesda, MD. The alcoholic subjects had all been abstinent for at least 1 month prior to participation in the study. The remainder of the control subjects participated in the study as outpatients. All controls were asked to abstain from drinking any alcoholic beverage for $48 \mathrm{hr}$ prior to the acetylator phenotype testing. Compliance was tested with a breath alcohol test which was required to be negative prior to beginning the acetylation phenotyping procedure. All subjects signed an informed consent form prior to participating in the study and control subjects were financially reimbursed.

There were 26 controls and 37 abstinent alcoholics. There was no significant difference in age between the two groups (controls: $49 \pm 15$ years vs. alcoholics: $46 \pm 20$ years). There was a higher proportion of women in the control group (11 of 26 vs. 4 of 37 ).

All subjects fasted from midnight on the day of the study, except for water, and received a $20-\mathrm{mg} / \mathbf{k g}$ oral dose of sodium sulfamethazine solution in the morning between $6: 45$ and 8 a.m. The subjects then continued fasting, with the exception of water, for an additional $3 \mathrm{hr}$. Ten milliliters of blood were drawn from an antecubital vein into a vacutainer tube at $5 \mathrm{hr}$ following sulfamethazine administration.

Sulfamethazine serum samples were assayed using high-performance liquid chromatography with UV detection employing the method of Whelpton et al. ${ }^{21}$ The concentrations of both sulfamethazine (SMZ) and acetylsulfamethazine (ACSMZ) were determined directly by this method. The percentage acetylated at $5 \mathrm{hr}$ was calculated as follows (concentrations are expressed as $\mathrm{mcg} / \mathrm{ml}^{2}$ :

$$
\frac{[\mathrm{ACSMZ}]}{[\mathrm{ACSMZ}]+[\mathrm{SMZ}]} \times 100=\% \text { of total concentration acetylated }
$$

\section{RESULTS}

The proportions in the two groups were compared using a $\chi^{2}$ test. They did not differ from each other. The percentage acetylated at $5 \mathrm{hr}$ showed a bimodal distribution in both groups (Figs. 1 and 2). The cut-off point between fast and slow acetylators was set at $60 \%$, a posteriori. The alcoholic and control groups contained, respectively, $54 \%$ $(20 / 37)$ and $54 \%(14 / 26)$ fast acetylators. Eleven of the male alcoholic patients had a family history of alcoholism based on two first degree male relatives (father and either 
$\%$ acetylated at 5 hours in normals

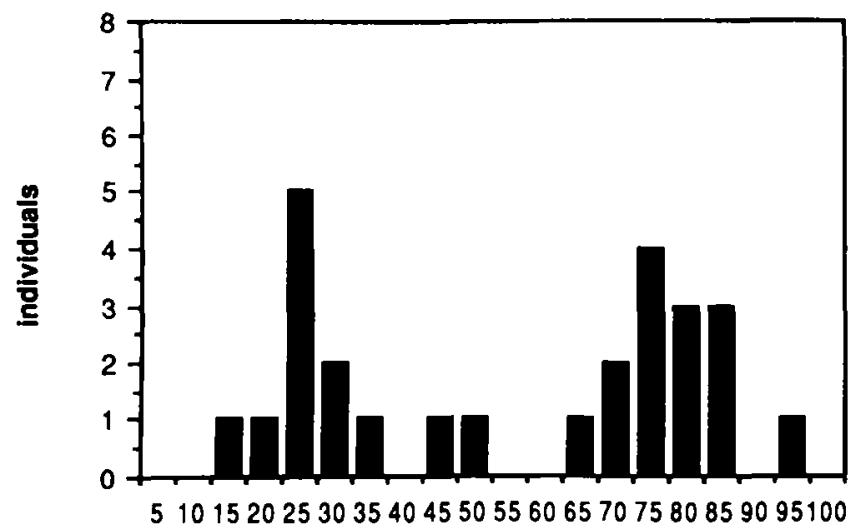

Fig. 1. The percentage of plasma sulfamethazine acetylated at $5 \mathrm{hr}$ following oral administration to 26 control subjects.

\section{$\%$ acetylated at 5 hours in alcoholics}

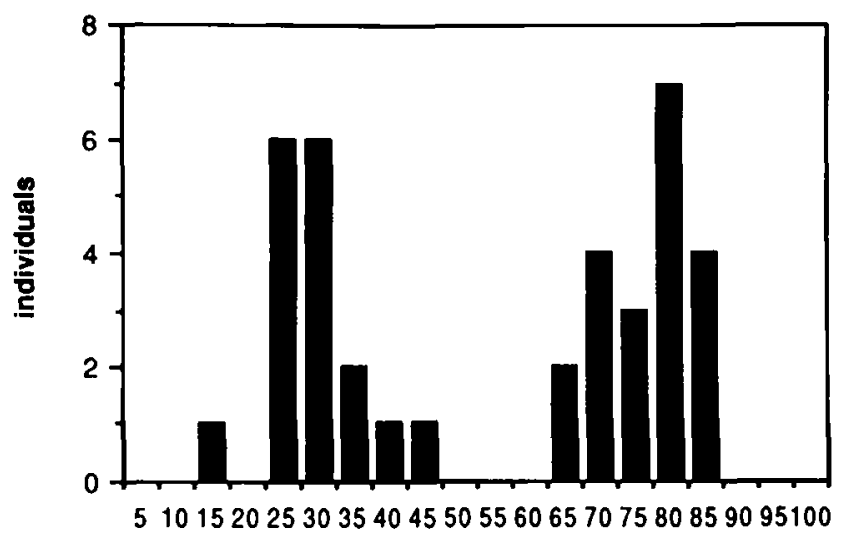

Fig. 2. The percentage of plasma sulfamethazine acetylated at $5 \mathrm{hr}$ following oral administration to $\mathbf{3 7}$ abstinent alcoholics.

paternal grandfather, brother or son). Six of them were rapid and five were slow acetylators of sulfamethazine, which is no different from the proportion in the control subjects.

No side-effects to the sulfamethazine were noted, with the exception of one complaint of a headache.

\section{DISCUSSION}

Our study revealed no difference in the proportions of slow or fast acetylators in abstinent alcoholics when compared to normal volunteers.

Acetylator phenotype is genetically determined by two autosomal alleles and governs the metabolic rates of many drugs undergoing acetylation. Although three genotypes (fast, moderate, slow) exist for acetylation, ${ }^{23}$ most commonly used techniques for determining acetylation phenotype only discriminate between "fast" and "slow" acetylators. Intermediate acetylators are included with fast acetylators when abbreviated tests, such as the one used in this study, are used. Acetylation rate may have a strong bearing on drug efficacy and also upon the presence of certain side-effects, especially when an acetylation step is the major activating or deactivating step in the metabolic pathway, e.g., isoniazid and hydralazine. Additionally, the slow acetylators show a greater incidence of arylamineinduced bladder cancer, since they detoxify arylamines more slowly than fast acetylators. ${ }^{24.25}$ Two studies ${ }^{26.27}$ have also found an association between acetylator phenotype and personality traits. These personality traits (neuroticism and hypochondriasis) cannot be simply related to those ascribed to Type 1 and Type 2 alcoholics as described by Cloninger. ${ }^{14}$

In the initial acetylation phenotyping studies, ${ }^{25.28}$ acetylation phenotype appeared to be uninfluenced by either age or gender. However, recent studies report that both gender and age affect isoniazid acetylation rate. ${ }^{29.30} \mathrm{Gach}$ alyi et al. ${ }^{31}$ have also reported that age affects acetylator phenotype when it is determined using sulfamethazine. There was no significant difference in age between our two groups. Since gender has not been shown to be a significant source of variability when sulfamethazine is used as a phenotyping agent the greater number of females in our control group most likely had no effect on the results.

Our phenotype results (54\% fast, and $46 \%$ slow in each group) are in general agreement to those reported for the caucasian population, $52 \%$ fast and $48 \%$ slow. ${ }^{32}$ A power analysis based on our current results reveals that, should there be a significant difference $\left(\alpha=0.05, Z_{c r}=1.96\right)$ between the two groups, a sample size of 2430 subjects would be required in each group to demonstrate this difference with a power of $80 \%\left(1-\beta=0.8, Z_{\beta^{\prime}}=0.84\right)$. Based upon this information a significant association between acetylation phenotype and the presence of alcohol abuse or dependence is very unlikely.

\section{REFERENCES}

1. Kaij L: Studies on the etiology and sequels of abuse of alcohol. Lund, Sweden, University of Lund, 1960

2. Hrubec Z, Omenn BS: Evidence of genetic predisposition to alcoholic cirrhosis and psychosis: Twin concordances for alcoholism and its biological end points by zygosity among male veterans. Alcohol Clin Exp Res 5:207-215, 1981

3. Shuckit MA, Goodwin DA. Winokur G: A study of alcoholism in half siblings. Am J Psychiatry 128:1132-1136, 1972

4. Goodwin DW, Schulsinger F, Hermansen L, Guze SB, Winokur G: Alcohol problems in adoptees raised apart from alcoholic biological parents. Arch Gen Psychiatry 28:238-243, 1973

5. Goodwin DW, Schulsinger F, Moller N, Hermansen L, Winokur $G$, Guze SB: Drinking problems in adopted and nonadopted sons of alcoholics. Arch Gen Psychiatry 31:164-169, 1974

6. von Knorring A-L, Cloninger CR, Bohman M. Sigvardsson S: An adoption study of depressive disorders and substance abuse. Arch Gen Psychiatry 40:943-950, 1983

7. Hill SY, Goodwin DW, Cadoret R, Osterland CK, Doner SM: Association and linkage between alcoholism and eleven serological markers. J Stud Alcohol 36:981-992, 1975

8. Sullivan JL, Cavenar JO, Maltbie AA, Lister P, Zung WWK: Familial biochemical and clinical correlates of alcoholics with low platelet monoamine oxidase activity. Biol Psychiatry 14:385-394, 1979

9. Schuckit MA, Shaskan E, Duby J, Vega R, Moss M: Platelet 
monoamine oxidase activity in relatives of alcoholics. Arch Gen Psychiatry 39:137-140,1982

10. Tabakoff B, Hoffman P, Lee JM, Saito T, Willard B, De LeonJones F: Differences in platelet enzyme activity between alcoholics and nonalcoholics. N Engl J Med 318:134-139, 1988

11. Evans DAP, Manley KA, McKusick VA: Genetic Control of isoniazid metabolism in man. Br Med J 2:485-491, 1960

12. Weber WW, Hein DW: $N$-Acetylation Pharmacogenetics. Pharmacol Rev 37:25-79, 1985

13. Olsen $\mathrm{H}$, Morland $\mathrm{J}$ : Ethanol-induced increase in procainamide acetylation in man. Br J Clin Pharmacol 13:203-208, 1982

14. Cloninger CR: Neurogenetic adaptive mechanisms in alcoholism. Science (Wash DC) 236:410-416, 1987

15. Asberg M, Traskman L, Thoren P: SHIAA in the cerebrospinal fluid. Arch Gen Psychiatry 33:1193-1197, 1976

16. Brown GL, Goodwin FK, Ballenger JC, Goyer PF, Major LF: Aggression in humans correlates with cerebrospinal fluid amine metabolites. Psychiatry Res 1:131-139, 1979

17. Traskman L, Asberg M, Bertilsson L, Sjostrand L: Monoamine metabolites in CSF and suicidal behavior. Arch Gen Psychiatry 38:631636,1981

18. Linnoila $M$, Virkkunen $M$, Scheinin $M$, Nuvtila A, Rinion $R$, Goodwin FK: Low cerebrospinal fluid 5-hydroxyindole acetic acid concentration differentiates impulsive from nonimpulsive violent behavior. Life Sci 33:2609-2614, 1983

19. American Psychiatric Association Taskforce on Nomenclature and Statistics: Diagnostic and statistical manual of mental disorders, 3rd ed., American Psychiatric Association, Washington, DC, 1980

20. Spitzer RL, Endicott J: Schedule for affective disorders and schizophrenia: Lifetime version, ed. 3. New York, New York State Psychiatric Institute, 1979

21. Whelpton R, Watkins G, Curry SH: Bratton-Marshall and liquid- chromatographic methods compared for determination of sulfamethazine acetylator status. Clin Chem 27:1911-1914. 1981

22. Evans DAP: An improved and simplified method of detecting the acetylator phenotype. J Med Genet 6:405-407, 1969

23. Chapron DJ, Kramer PA. Mercik SA: Kinetic discrimination of three sulfamethazine acetylation phenotypes. Clin Pharmacol Ther 27:104-113, 1980

24. Cartwright RA, Glashan RW, Rogers HJ, Ahmad RA. Hall DB. Higgins E, Kahn MA: The role of $N$-acetyltransferase phenotypes in bladder carcinogenesis: A pharmacogenetic epidemiological approach to bladder cancer. Lancet 2:842-846, 1982

25. Evans DAP, Eze LC, Whitley EJ: The association of the slow acetylator phenotype with bladder cancer. J Med Genet 20:330-333, 1983

26. Tyrer P, Gardner M. Lambourn J, Whitford M: Dosage and acetylator status in clinical response to phenelzine, in Youdim MBH. Paykel ES (eds), Monoamine Oxidase Inhibitors: The State of the Art. London: John Wiley \& Sons, 1981, p 149

27. Saiz-Ruiz J, Aguilera JC: Personality traits and acetylator status. Biol Psychiatry 20:1138-1140, 1985

28. Farah F, Taylor W, Rawlins MD, James O: Hepatic drug acetylation and oxidation: effects of aging in man. $\mathrm{Br}$ Med $\mathrm{J} 2: 155-156,1977$

29. Iselius L, Evans DAP: Formal genetics of isoniazid metabolism in man. Clin Pharmacokinet 8:541-544, 1983

30. Paulsen O, Nilsson LG: Distribution of acetylator phenotype in relation to age and sex in Swedish patients. Eur J Clin Pharmacol 28:311315,1985

31. Gachalyi B, Vas A, Hajos P. Kaldor A: Acetylator phenotypes: effect of age. Eur J Clin Pharmacol 26:43-45, 1984

32. Vree TB. Hekster YA, Tijhuis MV: Metabolism of sulfonamides, in Vree TB, Hekster YA (eds), Pharmacokinetics of Sulfonamides Revisited. (Antibiotics and Chemotherapy; vol 34). New York: Karger, 1985, p 5 